\section{Robins and Rainbows}

\author{
Lloyd T. Carmichael, Regina
}

The week before Christmas was exceptionally mild in the Queen City. Robins were seen during the week by Bert Johnson, Eric Hammerstrom, Horace Croome, George Ledingham and many others. They seemed contented and in no hurry to continue their trip to the south. But the warm spell was crowned also with a real weather phenomenon on Wednesday afternoon, December 22 , when a rainbow appeared over northeast Regina. At $3: 40$ p.m. the sun broke through rain clouds and caused the rainbow which lasted until sunset, nearly twenty minutes later. Many stood on the streets and watched the unusual, sight and no doubt the robins also hailed it as a good omen and decided to tarry for a few more days.

It turned cold on the night of December 28, touching ten degrees below zern. As I walked to work the next morning I found one robin who had procrastinated too long. He lay dead and frozen near the sidewalk, under a spreading elm tree where he had sought shelter for the night.

Robins, apparently, have a rugged constitution, for some did survive many nights of subzero temperatures although not extreme ones - never below ten below. On Sunday, January 23rd a Robiin accompanied by a Downy Woodpecker and a Chickadee visited again the back yard of Mr. and Mrs. Croome, at 2310 Smith Street, Regina. The temperature was about ten degrees and a quiet snow was falling, adding its quota to the foot or more already on the ground. The bones of a turkey carcass frozen into the bird bath, fat-filled holes in a short length of a poplar pole, bread crumbs and scraps in suitable receptacles distributed around the yard proved a drawing card, not only to these birds but to the ever present English Sparrows.

Then the remarkable occurrence happened. This feeding yard proved such an attraction that the Robin, fluffed out against the wintery blasts, returned on January 26 . When observed, the temperature was 25 degrees below zero.

\section{Mother Love and Intelligence}

\author{
K. E. Baines, Tisdale, Sask.
}

In pursuing our vocation of beekeeping it is common practise to locate an apiary on the site of an abandoned home. One such location was about two miles east of Tisdale. On the sunny side of a few acres of poplar are some caving in holes, charred wood, a row of lilac and another of carragana, and a few stray evening-scented stocks. The road goes by half a mile away and the nearest occupied habitation is a little further off.

Such was the picture when Doug and I called to check over the bees one bright June morning. As soon as we got out of the truck, a thin collie dog came running out of the bush, whining and acting very peculiarly. It occurred to me she might be mad but she did not come too close to us as we worked on the bees. There was a freshly worn path leading 'back of the hives and into the bush. We spent about an hour on the bees and the dog was still around and seemingly agitated.

We walked over to the truck to go and, just as I placed one foot on the running board to get in, the dog came up behind me and nipped my coat. I whirled, thinking she was getting vicious, and as I faced her she turned and started down the path, indicating to me as plainly as if she had spoken, that I was to follow her. Down the path she went with me after. Just inside the bush was an old well hole about ten feet deep and quite dry. There at the bottom was a fat, sleek pup. It took only a few minutes to lower Doug on a rope and he passed the pup up to me. I set him down and mother and pup headed off across the field, without looking back.

We checked over all the signs and decided the pup had been trapped in the hole for at least a week. There were feathers and remains of gophers and mice in the bottom. The mother had not allowed her offspring to go hungry even if she could not get him out.

How did she know that a strange man could help her? 